\title{
Opinions of pediatric nurses about Jehovah's Witnesses refusal of blood transfusion for their child
}

Opinie pielęgniarek pediatrycznych wobec odmowy Świadków Jehowy na leczenie swojego dziecka krwią

\section{Klaudia Jakubowska' ', Barbara Kuczek' , Anna Wiśniewska², Anna Pilewska-Kozak³, Beata Dobrowolska'}

\begin{abstract}
'Department of Development in Nursing, Faculty of Health Sciences, Medical University of Lublin, Poland/ Katedra Rozwoju Pielęgniarstwa, Wydział Nauk o Zdrowiu, Uniwersytet Medyczny w Lublinie, Polska 2Department of Family Medicine and Community Nursing, Faculty of Health Sciences, Medical University of Lublin/ Zakład Medycyny Rodzinnej i Pielęgniarstwa Środowiskowego, Wydział Nauk o Zdrowiu, Uniwersytet Medyczny w Lublinie, Polska 3Chair and Department of Gynecology and Gynecological Endocrinology, Faculty of Health Sciences, Medical University of Lublin, Poland/ Katedra i Klinika Ginekologii i Endokrynologii Ginekologicznej, Wydział Nauk o Zdrowiu, Uniwersytet Medyczny w Lublinie, Polska
\end{abstract}

\section{AUTOR DO KORESPONDENCJI/CORRESPONDING AUTHOR: \\ Klaudia Jakubowska \\ Department of Development in Nursing, Faculty of Health Sciences, Medical University of Lublin Katedra Rozwoju Pielęgniarstwa, WNoZ, UM w Lublinie ul. Staszica 4/6, 20-250 Lublin e-mail: klaudia.massalska@umlub.pl}

STRESZCZENIE OPINIE PIELECNIAREK PEDIATRYCZNYCH WOBEC ODMOWN ŚWIADKÓW JEHOWN NA LECZENIE SWOJEGO DZLECCKA KRWIA

Wstęp. Świadkowie Jehowy stanowczo sprzeciwiają się transfuzji krwi. Sytuacja jest szczególnie trudna, kiedy odmowa leczenia krwią dotyczy dziecka. Pomimo istniejących rozwiązań prawnych, personel medyczny doświadcza konfliktów wartości.

Cel pracy. Analiza opinii pielęgniarek pediatrycznych na temat problemów jakie mogą się pojawić w sytuacji odmowy leczenia krwią dziecka Świadków Jehowy.

Materiał i metodyka. Zrealizowano badania o charakterze ilościowym metodą sondażu diagnostycznego. Do pomiaru zmiennych wykorzystano autorski kwestionariusz ankiety. W badaniach uczestniczyła grupa 104 pielęgniarek pediatrycznych południowowschodniej Polski.

Wyniki. Na pytanie „Czy w czasie swojej pracy zawodowej znalazł/a się Pani/Pan w sytuacji, kiedy rodzice nie wyrazili zgody na leczenie krwiq dziecka z powodu wiary?", 67,31\% (n=70) ankietowanych odpowiedziało, że rzadko, miała miejsce taka sytuacja. Połowa badanych pielęgniarek ( $n=52 ; 50,02 \%$ ) przyznała, że nie akceptuje stanowiska Świadków Jehowy wobec leczenia krwią. Większość badanych pielęgniarek 87,38\% (n=89) uważa za potrzebne istnienie procedur, które przedstawiają zapisy o tym jak należy postępować w tej trudnej sytuacji, a 83\% ( $n=86$ ) badanych przyznała, że nie ma innego lepszego rozwiązania niż obecna procedura prawna.

Wnioski. Najtrudniejszym doświadczeniem pielęgniarek w sytuacji odmowy leczenia krwią dziecka Świadków Jehowy jest w opinii badanych narażenie dziecka na utratę zdrowia czy nawet śmierć. Dlatego większość badanych uważa, że dobrym rozwiązaniem w takich przypadkach jest wdrożenie procedury prawnej, która pozwala na transfuzję pomimo sprzeciwu rodziców.

Słowa kluczowe: pielęgniarki pediatryczne, Świadkowie Jehowy, leczenie krwią, problemy etyczne

ABSTRACT OPINIONS OF PEDIATRIC NURSES ABOUT JEHOVAH'S WITNESSES REFUSAL OF BLOOD TRANSFUSION FOR THEER CHIL D

Introduction. Jehovah's Witnesses absolutely refuse having blood transfusion performed. The situation is even more difficult when the refusal of blood transfusion concerns a child. Despite existing legal solutions, medical staff experiences value conflicts.

Aim. To analyze the opinions of pediatric nurses about problems that may arise in case of Jehovah's Witnesses refusal of blood transfusion for their child.

Material and methods. Quantitative research was based on a diagnostic survey method. The variables were measured with the use of a survey questionnaire co-developed by the authors. A group of 104 pediatric nurses from the South-East Poland participated in the study. Results. To the question "Have you ever encountered the situation throughout all your working career when parents refused their child to undergo a blood treatment due to their beliefs?", $67.31 \%(n=70)$ of the respondents replied the situation rarely happened. Half of the nurses surveyed $(n=52,50.02 \%$ ) admitted they did not accept the position of Jehovah's Witnesses concerning blood treatment. Most of the nurses surveyed $-87.38 \%(n=89)$ think the existence of procedures on how to proceed in this difficult situation is crucial, and $83 \%(n=86)$ of the respondents admitted that there was no better solution than the already existing legal procedure. Conclusions. The most difficult experience of pediatric nurses in the situation of Jehovah's Witnesses refusal of blood transfusion for their child is in the opinion of surveyed nurses, endangering the child's health or even life. Thus, most of the respondents agree that the best solution in that case is to implement a legal procedure that allows blood transfusion despite parents' refusal. 


\section{INTRODUCTION}

The profession of a nurse belongs to a group of professions requiring high professional qualifications and specific ethical attitudes. The attitude of the nurse to world of values is often of significant importance to the process of care, which becomes particularly evident in the face of such experiences as an illness, suffering and death of the patient [1].

Blood transfusion is an increased risk procedure and requires the patient's written consent to perform it. The patient is guaranteed by law the right to refuse consent to carry out the transfusion without the need to justify his position. This, however, often generates medical and ethical problems, both in the patient-doctor and the patient-nurse relationships [2].

Jehovah's Witnesses are firmly opposed to blood transfusions referring to the records of the Old and New Testaments to refrain from blood. Their justifications have numerous implications from religious and cultural, through pragmatic and ethical ones [3]. At the same time, Jehovah's Witnesses are a well-organized group with deep knowledge on treatment, particularly in the areas of haematology, serology, transfusiology and immunology. They expect treatment respecting the right to patient autonomy. They are also open to exchange of views and cooperation with the hospital team. In severe cases it happens that some of them, referring to their own conscience, ultimately agree to use their own blood, providing that it does not lose communication with the bloodstream [4].

The situation is particularly difficult when the patient is a child who alone cannot take a decision regarding the therapeutic methods applied. In this specific case, parents' decision to refuse a transfusion is usually incomprehensible to medical personnel. It is assumed that both parents of the child and medical personnel should act in their best interest, which in this case is the same as protection of his/her life and health. Therefore, in the case of a person who is a minor, and a blood transfusion may be necessary to save his/her life, the doctor may ask for court interference. Parents' authority may be judicially limited in order to save the child's life $[5,6]$.

\section{AIM}

The aim of the presented study was to analyze the opinions of pediatric nurses about problems that may arise in case of Jehovah's Witnesses refusal of blood transfusion for their child.

\section{MATERIALS AND METHODS}

In the studies conducted among the group of pediatric nurses, the diagnostic survey method with the use of a questionnaire co-developed by the authors were used. The study was carried out in accordance with the principles of the Declaration of Helsinki. Each nurse invited to participate in the study was informed about its purpose and ensured the complete anonymity of the collected data. The respondents also received information about the possibility of withdrawal from participation in the study. The consent for the study was also obtained from the directors of the institutions where the data was collected.
The statistical analysis was carried out using the STATISTICA 12 software (StatSoft Poland) and Microsoft Excel 2010 .

\section{RESULTS}

The surveyed group consisted of professionally active nurses - 104 (100\%) aged 23-63 (the average age of respondents -40.75 years old). The study was conducted among pediatric nurses working in the South-East part of Poland. The detailed data on the sociodemographic characteristics of the respondents is provided in Tab. 1.

Tab. 1. Sociodemographic data of the respondents

\begin{tabular}{|c|c|c|}
\hline Sociodemographic variables & $\mathbf{n}$ & $\%$ \\
\hline \multicolumn{3}{|l|}{ Age } \\
\hline $23-40$ years old & 46 & $44.20 \%$ \\
\hline 41-63 years old & 58 & $55.80 \%$ \\
\hline \multicolumn{3}{|l|}{ Material status } \\
\hline Married woman & 67 & $64.42 \%$ \\
\hline Unmarried woman & 20 & $19.23 \%$ \\
\hline Widow & 17 & $16.35 \%$ \\
\hline Total: & 104 & $100 \%$ \\
\hline \multicolumn{3}{|l|}{ Place of residence } \\
\hline Countryside & 22 & $21.15 \%$ \\
\hline City inhabited by up to 5 thousand citizens & 14 & $13.46 \%$ \\
\hline City inhabited by up to 100 thousand citizens & 32 & $30.77 \%$ \\
\hline City inhabited by from 101 up to 500 thousand citizens & 30 & $28.85 \%$ \\
\hline City inhabited by above 501 thousand citizens & 6 & $5.77 \%$ \\
\hline Total: & 104 & $100 \%$ \\
\hline \multicolumn{3}{|l|}{ Job seniority } \\
\hline Less than 5 years & 18 & $17.31 \%$ \\
\hline From 6 to 15 years & 32 & $30.77 \%$ \\
\hline From 16 to 25 years & 21 & $20.19 \%$ \\
\hline Over 25 years & 33 & $31.73 \%$ \\
\hline Total: & 104 & $100 \%$ \\
\hline \multicolumn{3}{|l|}{ Education } \\
\hline Medical school & 10 & $9.62 \%$ \\
\hline Medical post-secondary school & 24 & $23.08 \%$ \\
\hline Bachelor of Science in Nursing & 36 & $34.62 \%$ \\
\hline Master of Science in Nursing & 33 & $31.72 \%$ \\
\hline Doctor of Medical Sciences & 1 & $0.96 \%$ \\
\hline Total: & 104 & $100 \%$ \\
\hline
\end{tabular}

The vast majority of nurses $(n=87 ; 83.65 \%)$ had contact with patients who were Jehovah's Witnesses. The remaining $16.35 \%$ of the respondents $(n=17)$ have never met such a patient in their work environment. To the question „Have you ever encountered the situation throughout all your working career when parents refused their child to undergo a blood treatment due to their beliefs?", $34.62 \%(n=36)$ of the respondents replied that it was a very rare case, and $32.69 \%(\mathrm{n}=34)$ that such a situation seldom occurred. When it comes to $18.27 \%(\mathrm{n}=19)$ 
of the respondents, they have never experienced such an event, $9.62 \%(n=10)$ of the respondents cannot remember such an event, and $4.81 \%(n=5)$ of nurses declare that they have repeatedly witnessed such a situation. The majority of the respondents $(n=35,33.65 \%)$ admitted that they did not try to convince parents to change their decision to refuse blood transfusions, $25.96 \%$ $(n=27)$ of the respondents confirmed that they sporadically tried to influence their parents' decision, while $18.27 \%(n=19)$ of the respondents stated that they repeatedly tried to convince parents to change their decision on blood treatment for their child. A large group of nurses did not remember what they did in those situations ( $n=16 ; 15.38 \%)$, and $6.37 \%(n=7)$ of the respondents replied the question did not concern them because they had never experienced such an event before.

Half of the nurses surveyed $(n=52 ; 50.02 \%)$ admitted that they did not accept the position of Jehovah's Witnesses regarding blood treatment (with blood products), 29.81\% $(n=31)$ of the respondents had no opinion on the matter, and the remaining $20.19 \%(\mathrm{n}=21)$ accepted this position.

The open question: what was the most difficult for nurses in the situation of Jehovah's Witnesses refusal of blood transfusion for their child? was most often responded that the most difficult thing was endangering the child's health or even life $(n=36)$. The nurses' comments were divided into five thematic categories (Tab. 2).

Nearly half of the nurses surveyed ( $\mathrm{n}=49,47.12 \%$ ) denied that the refusal of consent to treatment led to a significant deterioration of the child's health or harm to their health, $34.62 \%(n=36)$ of the surveyed reported, that in their professional practice such situations occurred very rarely, $13.46 \%(n=14)$ of the respondents replied that such events were rare, while the remaining $4.81 \%$ $(n=5)$ of the respondents repeatedly witnessed such situations. During their professional work, $81.73 \%$ $(n=85)$ of the respondents have never witnessed the death of a child because of parents' refusal of blood transfusion for their child, and $12.50 \%(n=13)$ of nurses surveyed admitted that, though rarely, they have witnessed such events, $4.81 \%(\mathrm{n}=5)$ have also participated in such a situation, but again, very rarely. One person $(0.96 \%)$ admitted that she repeatedly witnessed the death of a child because of the parents' refusal of blood transfusion for their child.

Nurses were asked about their feelings in the situation where, in their opinion, parents did not act for the sake of their child and made wrong decisions about further treatment or cessation of treatment. The analysis of the data shows that the most frequently chosen statement was "I am worried” ( $\mathrm{n}=50)$ and "I feel anger" $(\mathrm{n}=44)$, while the rarest one was „I feel indifferent" $(\mathrm{n}=2)$. Detailed data is presented in Tab. 3 .

Almost half of the nurses surveyed - 45.19\% $(n=47)$ strongly believes that the procedures providing records on how to deal with this difficult situation are essential, and $40.38 \%(n=42)$ of the respondents support the usefulness of such procedures. When it comes to $10.58 \%(n=42)$ of the surveyed, they did not have any opinion on the matter, and $3.85 \%(n=4)$ of the respondents stated that they did not see the point of existence of such records. More than a half of the respondents $(n=57 ; 55 \%)$ admitted that using the legal procedure in a situation when parents do not give their consent to treatment because of their beliefs is "rather” a good solution, $22 \%(n=23)$ of the respondents think that another solution should be sought, $16 \%$ $(n=16)$ of the respondents strongly admit that the legal procedure is the best way in such a situation, while $7 \%$ $(n=7)$ of the respondents feel quite the opposite.

Tab. 2. Categories of the respondents' opinions on the difficulties experienced in the situation of Jehovah's Witnesses refusal of blood treatment for their child

\begin{tabular}{|c|c|}
\hline $\begin{array}{l}\text { What is the most difficult for you in the situation of Jehovah's } \\
\text { Witnesses refusal of blood treatment for their child? }\end{array}$ & $\mathbf{n}^{*}$ \\
\hline \multicolumn{2}{|l|}{ Responses strictly connected with fear for the child's health condition } \\
\hline Endangering the child's health or even life & 36 \\
\hline Fear for the child's health and life & 34 \\
\hline Helplessness and awareness that the child's life might be saved & 12 \\
\hline $\begin{array}{l}\text { Jehovah's Witnesses refusal of blood transfusion for their child as such } \\
\text { and the consequences of such a decision }\end{array}$ & 7 \\
\hline The child's death & 4 \\
\hline \multicolumn{2}{|l|}{$\begin{array}{c}\text { Responses strictly connected with the attitude towards parents } \\
\text { being Jehovah's Witnesses }\end{array}$} \\
\hline Lack of understanding for parents' decisions & 10 \\
\hline Awareness that parents deprive their child of a chance to be cured & 8 \\
\hline Accepting the reason for the parents' decision & 5 \\
\hline Encouraging parents to change their decision & 2 \\
\hline \multicolumn{2}{|l|}{ Difficulty in understanding the views of Jehovah's Witnesses } \\
\hline $\begin{array}{l}\text { The most difficult is to understand that this decision was made due to } \\
\text { religious views }\end{array}$ & 8 \\
\hline It is difficult to respect the child's parents' decision & 2 \\
\hline \multicolumn{2}{|l|}{ Respondents' replies related to their conscience } \\
\hline Sense of helplessness & 6 \\
\hline It is difficult for me to reconcile with my conscience and views & 4 \\
\hline Remorse despite no possibility to take an action & 2 \\
\hline Understanding the contradiction "life or faith" & 2 \\
\hline \multicolumn{2}{|l|}{ Positive or neutral responses } \\
\hline I have no opinion & 30 \\
\hline It is not a difficult situation, I understand their behavior & 5 \\
\hline $\begin{array}{l}\text { It is not difficult, everyone has the right to follow their views and } \\
\text { opinions }\end{array}$ & 4 \\
\hline I respect their decision & 1 \\
\hline
\end{tabular}

* open question, respondent could give more than one response, data does not add up to $100 \%$

Tab. 3. Feelings of the respondents in a situation when parents do not act for the sake of their child and make wrong decisions about further treatment or cessation of treatment

\begin{tabular}{|l|c|}
\hline \multicolumn{1}{|c|}{ Responses } & $\mathbf{n}^{*}$ \\
\hline I am worried & 50 \\
\hline I feel anger & 44 \\
\hline I feel disappointment & 36 \\
\hline I feel sadness & 30 \\
\hline I empathize with the parents'situation & 25 \\
\hline I identify with the patient's situation & 9 \\
\hline I feel indifferent & 2 \\
\hline I feel nothing because of the fact & 9 \\
\hline
\end{tabular}

* open question, respondent could give more than one response, data does not add up to $100 \%$ 
In the respondents' experience, the legal procedure is always implemented when there is a danger to the child's life as a result of the parents' decision to refuse blood treatment $(\mathrm{n}=33 ; 31.73 \%)$, and $25.96 \%(\mathrm{n}=27)$ of the nurses have never encountered such a situation (Tab. 4).

Tab. 4. Responses of nurses on the implementation of the legal procedure in the situation of parents' refusal of blood transfusion for their child

\begin{tabular}{|l|c|c|}
\hline \multicolumn{1}{|c|}{ Responses } & $\mathbf{n}$ & $\%$ \\
\hline Always, when the child's life is endangered & 33 & 31.73 \\
\hline I have never encountered such a situation & 27 & 25.96 \\
\hline $\begin{array}{l}\text { Very rarely, a legal procedure is valid only in specific } \\
\text { and hard cases }\end{array}$ & 23 & 22.12 \\
\hline $\begin{array}{l}\text { Usually, when the suggested treatment } \\
\text { (unaccepted by parents) is most beneficial for the child }\end{array}$ & 15 & 14.42 \\
\hline $\begin{array}{l}\text { Rarely, because there are other treatment methods } \\
\text { available (accepted by parents) }\end{array}$ & 6 & 5.77 \\
\hline Total & 104 & 100 \\
\hline
\end{tabular}

Nurses were asked whether the above legal procedure was implemented at their workplace immediately after the decision of the child's parents. Among all the responses, the most frequent one was "no, first, there are discussions held to convince parents to change their decision" ( $\mathrm{n}=28$, $26.92 \%$ ), and the least often „yes, but the legal procedure requires time" ( $\mathrm{n}=1211.54 \%)$. When it comes to $2.88 \%$ $(\mathrm{n}=3)$ of the respondents, they refrained from giving their opinion, giving the response „I do not know” (Tab. 5).

Tab. 5. Experiences of the respondents on the implementation of the legal procedure after presenting parents' decisions

\begin{tabular}{|l|c|c|}
\hline \multicolumn{1}{|c|}{ Responses } & $\mathbf{n}$ & $\%$ \\
\hline $\begin{array}{l}\text { No, first, there are discussions held to convince parents to } \\
\text { change their decision }\end{array}$ & 28 & 26.92 \\
\hline $\begin{array}{l}\text { It depends on the condition of the child who is to undergo } \\
\text { blood transfusion }\end{array}$ & 26 & 25.00 \\
\hline $\begin{array}{l}\text { No, first, we inform parents on the intention of } \\
\text { implementing the legal procedure, and then we give them } \\
\text { enough time to reconsider and redetermine their position }\end{array}$ & 19 & 18.27 \\
\hline $\begin{array}{l}\text { Yes, the problem is immediately reported to appropriate } \\
\text { institutions }\end{array}$ & 16 & 15.38 \\
\hline Yes, but the legal procedure requires time & 12 & 11.55 \\
\hline I do not know & 3 & 2.88 \\
\hline Total & 104 & 100 \\
\hline
\end{tabular}

More than half of the respondents $(n=68,65.38 \%)$ admitted that in their professional work they did not encounter the situation when parents changed their mind about the treatment of their child before implementation of the legal procedure, and $34.62 \%(n=36)$ of the respondents replied that it happened to be the case for parents to agree to the treatment suggested by the doctor before implementing the legal procedure. The question „Do you think, there is a different, better solution than the existing legal procedure?" was replied by $83 \%$ of respondents $(n=86)$ that there was no better solution than the current legal procedure. When it comes to $17 \%$ of the respondents $(\mathrm{n}=18)$, they were of a different opinion. They thought that there were other better solutions, e.g. talking to parents or legal guardians and persuading them to change their decisions.

According to the collected data, $14 \%(\mathrm{n}=15)$ of the respondents followed lawyer's advice in a morally and legally difficult situation occurring in their workplace, while the remaining $86 \%(n=89)$ did not take such an action. Moreover, $58.66 \%(n=61)$ of the respondents support the functioning of the so-called expert in occupational ethics who could provide help in ethically complicated situations, while $16.34 \%(n=17)$ are of the opposite opinion, and the remaining $25 \%(\mathrm{n}=26)$ have no opinion on the matter.

\section{DISCUSSION}

The position of Jehovah's Witnesses regarding blood transfusion is still a challenge for medicine and a subject of discussion, especially in severe clinical cases. The development of alternative therapies and applicable legal regulations both in Poland and in the world do not lead to unambiguous solutions and do not eliminate conflicts of values that are experienced in such cases by doctors and nurses $[2,7]$. This is particularly acute in the case of refusal of blood treatment for the child [6]. Despite the existence of alternative methods of treatment, for example, bloodless surgery, which are not always available in everyday clinical practice, the danger to the patient's life becomes real when the blood transfusion is not implemented [8-10]. At the same time, the fact of refusal of transfusion does not mean that Jehovah's Witnesses do not value life and do not fight for saving it, often seeking aggressive therapies. However, they expect these to remain in line with their religious beliefs $[3,10]$.

From a medical point of view, the position of Jehovah's Witnesses regarding the refusal of blood transfusion seems to be irrational [6]. This is reflected in the opinion of pediatric nurses surveyed, $50 \%$ of whom do not accept the position of Jehovah's Witnesses on this issue, and nearly $30 \%$ do not have an unambiguous opinion on this subject.

According to our own study, the most difficult experience of nurses in the situation of Jehovah's Witnesses refusal of blood treatment for their child is endangering their child's health or even life. In order to protect the life and health of the child, a legal procedure was introduced, which in the situation of the radical objection of the parents to their child undergoing blood transfusion allows the medical personnel to administer blood. Most of the nurses surveyed (85.57\%) believe that such legal solutions are indispensable and are the right solution (71\%). It is highlighted that before this procedure is implemented, all the available methods of therapy accepted by parents should be applied, with the aim of protecting the patient's safety. In addition, the child's parents should be systematically informed and updated on the process of conduct and the effects of the actions taken $[3,5]$. In our own study, nurses indicated that before the implementation of the legal procedure, discussions were held to convince parents to change their decision (26.92\%), and they were also 
allowed enough time to reconsider and redetermine their position $(18.27 \%)$. At the same time, the majority of the respondents $(65.38 \%)$ admitted that they did not encounter the situation where parents changed their decision on the blood treatment for their child.

From an ethical point of view, it is highlighted that open communication, without elements of coercion and scaring tactics, is the key in such situations. Communication, as well as empathy and support can help parents make a conscious and good decision $[3,5]$.

\section{CONCLUSIONS}

The most difficult experience of nurses in the situation of Jehovah's Witnesses refusal of blood transfusion for their child is, in the opinion of surveyed nurses, endangering the child's health or even life. Therefore, the majority of the respondents believe that a good solution in such cases is to implement a legal procedure that allows for a transfusion despite parents' objection.

\section{Opinie pielęgniarek pediatrycznych wobec odmowy Świadków Jehowy na leczenie swojego dziecka krwią}

\section{WSTĘP}

Zawód pielęgniarki należy do grupy profesji wymagających wysokich kwalifikacji zawodowych oraz określonych postaw etycznych. Stosunek pielęgniarki do świata wartości ma często istotne znaczenie w procesie opieki, co jest szczególnie widoczne w obliczu takich doświadczeń, jak choroba, cierpienie i śmierć pacjenta [1].

Transfuzja krwi jest zabiegiem o podwyższonym ryzyku i wymaga uzyskania pisemnej zgody pacjenta na jego wykonanie. Ustawowo pacjent ma zagwarantowane prawo odmowy udzielenia zgody na przeprowadzenie transfuzji bez potrzeby uzasadniania swojego stanowiska. To jednak generuje często problemy natury medycznej, ale i etycznej, zarówno w relacji pacjent-lekarz, jak i pacjent-pielęgniarka [2].

Swiadkowie Jehowy stanowczo sprzeciwiają się transfuzji krwi powołując się na zapisy Starego i Nowego Testamentu, by powstrzymywać się od krwi. Ich uzasadnienia mają liczne implikacje od religijno - kulturowych, poprzez pragmatyczne i etyczne [3]. Jednocześnie Świadkowie Jehowy stanowią grupę dobrze zorganizowaną, posiadającą wysoki poziom wiedzy na temat leczenia, szczególnie w dziedzinie hematologii, serologii, transfuzjologii czy immunologii. Oczekują terapii z poszanowaniem prawa do autonomii pacjenta, są również otwarci na wymianę poglądów i współpracę z zespołem szpitalnym. W ciężkich przypadkach zdarza się, że niektórzy, odwołując się do własnego sumienia, ostatecznie godzą się na zastosowanie własnej krwi, pod warunkiem, że nie utraci ona łączności z krwioobiegiem [4].

Sytuacja jest szczególnie trudna, kiedy pacjentem jest dziecko, które samo nie może podjąć decyzji dotyczącej stosowanych metod terapeutycznych. W tym specyficznym przypadku decyzja rodziców o odmowie transfuzji jest $\mathrm{z}$ reguły dla personelu medycznego niezrozumiała. Zakłada się, że zarówno rodzice dziecka jak i personel medyczny powinien działać w najlepszym dla niego interesie, który w tym przypadku jest tożsamy jako ochrona jego życia i zdrowia. Dlatego, w przypadku osoby, która jest nieletnia, a transfuzja krwi może być niezbędna do uratowania życia, lekarz może zwrócić się o ingerencję sądu. Władza rodziców może zostać sądownie ograniczona w celu ratowania życia dziecka $[5,6]$.

\section{CEL PRACY}

Celem prezentowanych badań była analiza opinii pielęgniarek pediatrycznych na temat problemów jakie mogą się pojawić w sytuacji odmowy leczenia krwią dziecka Świadków Jehowy.

\section{MATERIAŁ I METODA}

W badaniach, które przeprowadzono w grupie pielęgniarek pediatrycznych, zastosowano metodę sondażu diagnostycznego z wykorzystaniem kwestionariusza ankiety własnej konstrukcji. Badania przeprowadzono zgodnie z zasadami Deklaracji Helsińskiej. Każda pielęgniarka zaproszona do udziału w badaniu została poinformowana o celu badań oraz zapewniona o całkowitej anonimowości zgromadzonych danych. Respondenci otrzymali także informację o możliwości wycofania się z udziału w badaniach. Zgodę na badania otrzymano również od dyrektorów placówek, w których zbierano dane.

Analizę statystyczną przeprowadzono przy pomocy oprogramowania STATISTICA 12 (StatSoft Polska) i programu Microsoft Excel 2010.

\section{WYNIKI}

Grupę badaną stanowiły czynne zawodowo pielęgniarki - 104 osoby (100\%) w wieku 23-63 lata (średnia wieku badanych - 40,75 lat). Badania przeprowadzono wśród pielęgniarek pediatrycznych pracujących na terenie południowo-wschodniej Polski. Szczegółowe dane dotyczące cech socjodemograficznych respondentek zawiera tabela 1 . 
Tab. 1. Dane socjodemograficzne respondentek

\begin{tabular}{|c|c|c|}
\hline Zmienne socjodemograficzne & $\mathbf{n}$ & $\%$ \\
\hline \multicolumn{3}{|l|}{ Wiek } \\
\hline 23-40 lat & 46 & $44,20 \%$ \\
\hline 41-63 lata & 58 & $55,80 \%$ \\
\hline \multicolumn{3}{|l|}{ Stan cywilny } \\
\hline Zamężna & 67 & $64,42 \%$ \\
\hline Panna & 20 & $19,23 \%$ \\
\hline Wdowa & 17 & $16,35 \%$ \\
\hline Suma: & 104 & $100 \%$ \\
\hline \multicolumn{3}{|c|}{ Miejsce zamieszkania } \\
\hline Wieś & 22 & $21,15 \%$ \\
\hline Miasto do 5 tys. mieszkańców & 14 & $13,46 \%$ \\
\hline Miasto do 100 tys. mieszkańców & 32 & $30,77 \%$ \\
\hline Miasto od 101 tys. do 500 tys. mieszkańców & 30 & $28,85 \%$ \\
\hline Miasto powyżej 501 tys. mieszkańców & 6 & $5,77 \%$ \\
\hline Suma: & 104 & $100 \%$ \\
\hline \multicolumn{3}{|l|}{ Staż pracy } \\
\hline Poniżej 5 lat & 18 & $17,31 \%$ \\
\hline 6-15 lat & 32 & $30,77 \%$ \\
\hline $16-25$ lat & 21 & $20,19 \%$ \\
\hline Powyżej 25 lat & 33 & $31,73 \%$ \\
\hline Suma: & 104 & $100 \%$ \\
\hline \multicolumn{3}{|c|}{ Wykształcenie } \\
\hline Liceum medyczne & 10 & $9,62 \%$ \\
\hline Studium medyczne & 24 & $23,08 \%$ \\
\hline Licencjat pielęgniarstwa & 36 & $34,62 \%$ \\
\hline Magister pielęgniarstwa & 33 & $31,72 \%$ \\
\hline Doktor nauk medycznych & 1 & $0,96 \%$ \\
\hline Suma: & 104 & $100 \%$ \\
\hline
\end{tabular}

Zdecydowana większość pielęgniarek ( $\mathrm{n}=87 ; 83,65 \%)$ miała kontakt z pacjentami, którzy byli Świadkami Jehowy. Pozostałe $16,35 \%$ badanych $(n=17)$ nigdy nie spotkało się z takim pacjentem $\mathrm{w}$ swoim środowisku pracy. Na pytanie „Czy w czasie swojej pracy zawodowej znalazt/a się Pani/Pan w sytuacji, kiedy rodzice nie wyrazili zgody na leczenie krwia dziecka $z$ powodu wiary?", $34,62 \%$ $(\mathrm{n}=36)$ ankietowanych odpowiedziało, że bardzo rzadko, a $32,69 \%(n=34)$, że rzadko miała miejsce taka sytuacja. Nigdy nie doświadczyło takiego zdarzenia 18,27\% ( $\mathrm{n}=19)$ ankietowanych, 9,62\% $(\mathrm{n}=10)$ badanych nie pamięta takiego zdarzenia, zaś $4,81 \%(\mathrm{n}=5)$ pielęgniarek deklaruje, iż wielokrotnie były świadkami takiej sytuacji. Większość ankietowanych $(\mathrm{n}=35 ; 33,65 \%)$ przyznała, że nie próbowała przekonać rodziców do zmiany decyzji o odmowie transfuzji krwi, $25,96 \%(\mathrm{n}=27)$ badanych potwierdziło, że sporadycznie, ale próbowało wpłynąć na decyzję rodziców, zaś $18,27 \%(\mathrm{n}=19)$ respondentów wskazało, że wielokrotnie starali się przekonać rodziców do zmiany decyzji o leczeniu ich dziecka krwią. Spora grupa pielęgniarek nie pamiętała jak postąpiła w tej sytuacji $(\mathrm{n}=16 ; 15,38 \%)$, zaś $6,37 \%(n=7)$ ankietowanych odpowiedziało, że ponieważ nie doświadczyły takiego zdarzenia, to pytanie ich nie dotyczy.
Połowa badanych pielęgniarek $(\mathrm{n}=52 ; 50,02 \%)$ przyznała, że nie akceptuje stanowiska Świadków Jehowy wobec leczenia krwią (preparatami krwiopochodnymi), $29,81 \%(\mathrm{n}=31)$ badanych nie ma na ten temat zdania, zaś pozostałe $20,19 \%(n=21)$ akceptuje to stanowisko.

Na pytanie otwarte: co było dla pielegniarek najtrudniejsze w sytuacji odmowy leczenia krwia dziecka Świadków Jehowy? najczęściej padała odpowiedź, iż najtrudniejsze w tej sytuacji jest narażenie dziecka na uratę zdrowia bądź nawet śmierć $(\mathrm{n}=36)$. Wypowiedzi pielęgniarek podzielono na pięć tematycznych kategorii (tabela 2).

Tab. 2. Kategorie wypowiedzi respondentów w kwestii doświadczanych trudności w sytuacji odmowy leczenia krwią dziecka Świadków Jehowy

\begin{tabular}{|c|c|}
\hline $\begin{array}{l}\text { Co dla Pani/Pana jest najtrudniejsze w sytuacji odmowy } \\
\text { leczenia krwią dziecka Świadków Jehowy? }\end{array}$ & $\mathbf{n}^{*}$ \\
\hline \multicolumn{2}{|l|}{ Odpowiedzi bezpośrednio związane z obawą o zdrowie dziecka } \\
\hline Narażenie dziecka na uratę zdrowia bądź nawet śmierć & 36 \\
\hline Obawa o zdrowie i życie dziecka & 34 \\
\hline Bezradność i świadomość, że można by uratować to dziecko & 12 \\
\hline $\begin{array}{l}\text { Sama sytuacja odmowy leczenia krwią dziecka Świadków Jehowy } \\
\text { oraz skutki tej decyzji }\end{array}$ & 7 \\
\hline Śmierć dziecka & 4 \\
\hline \multicolumn{2}{|l|}{$\begin{array}{l}\text { Odpowiedzi bezpośrednio związane ze stosunkiem do rodziców } \\
\text { będących Świadkami Jehowy }\end{array}$} \\
\hline Brak zrozumienia dla decyzji rodziców & 10 \\
\hline Świadomość, że to rodzice pozbawiają swoje dziecko na szansę wyleczenia & 8 \\
\hline Pogodzenie się z powodem decyzji rodziców & 5 \\
\hline Chęćnakłonienia rodziców do zmiany decyzji & 2 \\
\hline \multicolumn{2}{|l|}{ Trudność w zrozumieniu poglądów Świadków Jehowy } \\
\hline $\begin{array}{l}\text { Najtrudniejsze jest zrozumienie, iż podjęto taką decyzję z powodu } \\
\text { poglądów religijnych }\end{array}$ & 8 \\
\hline Trudność sprawia poszanowanie decyzji rodziców dziecka & 2 \\
\hline \multicolumn{2}{|l|}{ Odpowiedzi respondentów związane z ich sumieniem } \\
\hline Poczucie bezradności & 6 \\
\hline Trudność sprawia mi pogodzenie się z własnym sumieniem i poglądami & 4 \\
\hline Wyrzuty sumienia pomimo braku możliwości działania & 2 \\
\hline Zrozumienie sprzeczności „życie czy wiara” & 2 \\
\hline \multicolumn{2}{|l|}{ Odpowiedzi pozytywne lub obojętne } \\
\hline Nie mam zdania & 30 \\
\hline Nie jest to trudna sytuacja, rozumiem ich postepowanie & 5 \\
\hline Nie jest to trudne, każdy ma prawo do swoich poglądów & 4 \\
\hline Szanuję ich decyzję & 1 \\
\hline
\end{tabular}

* pytanie otwarte, respondent mógł udzielić więcej niż jedną odpowiedź, dane nie sumują się do 100\%

Blisko połowa badanych pielęgniarek $(\mathrm{n}=49 ; 47,12 \%)$ zaprzeczyła, aby odmowa wyrażenia zgody na leczenie doprowadziła do znacznego pogorszenia się stanu zdrowia dziecka bądź doszło do uszczerbku na jego zdrowiu, $34,62 \%(n=36)$ badanych podało, że w ich praktyce zawodowej bardzo rzadko dochodziło do takich sytuacji, $13,46 \%(n=14)$ respondentów odpowiedziało, że takie zdarzenia miały miejsce rzadko, zaś pozostałe $4,81 \%(n=5)$ ankietowanych wielokrotnie było świadkami takich sytuacji. W czasie swojej pracy zawodowej $81,73 \%$ $(\mathrm{n}=85)$ badanych nigdy nie było świadkami śmierci 
dziecka z powodu odmowy leczenia krwią przez rodziców, zaś $12,50 \%(\mathrm{n}=13)$ badanych pielęgniarek przyznaje, iż rzadko, ale były świadkami takiego zdarzenia, $4,81 \%$ $(\mathrm{n}=5)$ również uczestniczyło w takiej sytuacji, ale bardzo rzadko. Jedna osoba $(0,96 \%)$ przyznała, że wielokrotnie była świadkiem śmierci dziecka z powodu odmowy leczenia krwią przez rodziców.

Zapytano o odczucia pielęgniarek w sytuacji, kiedy w ich opinii rodzice nie kierują się dobrem dziecka i podejmują błędne decyzje o dalszym leczeniu, bądź zaprzestaniu leczenia. $Z$ analizy danych wynika, że najczęściej wybieranym stwierdzeniem było "martwię się” $(\mathrm{n}=50)$ i „czuję złośc” $(\mathrm{n}=44)$, zaś najrzadszym „czuję obojętnośćc $(\mathrm{n}=2)$. Szczegółowe dane zawiera tabela 3.

Tab. 3. Odczucia ankietowanych w sytuacji, kiedy rodzice nie kierują się dobrem dziecka i podejmują błędne decyzje o dalszym leczeniu, bądź zaprzestaniu leczenia

\begin{tabular}{|l|c|}
\hline \multicolumn{1}{|c|}{ Odpowiedzi } & $\mathbf{n}^{*}$ \\
\hline Martwię się & 50 \\
\hline Czuję złość & 44 \\
\hline Czuję rozczarowanie & 36 \\
\hline Czuję smutek & 30 \\
\hline Wczuwam się w sytuację rodziców & 25 \\
\hline Utożsamiam się z sytuacją chorego & 9 \\
\hline Czuję obojętność & 2 \\
\hline Nie odczuwam nic z tego powodu & 9 \\
\hline
\end{tabular}

* pytanie otwarte, respondent mógł udzielić więcej niż jedną odpowiedź, dane nie sumują się do 100\%

Blisko połowa badanych pielęgniarek 45,19\% ( $n=47)$ zdecydowanie uważa za potrzebne istnienie procedur, które przedstawiają zapisy o tym jak należy postępować $\mathrm{w}$ tej trudnej sytuacji, a 40,38\% $(\mathrm{n}=42)$ respondentów raczej popiera przydatność tego typu procedur. Zdania w tym temacie nie miało $10,58 \%(n=42)$ badanych, zaś 3,85\% (n=4) ankietowanych podało, że nie widzi sensu istnienia takich zapisów. Ponad połowa ankietowanych $(\mathrm{n}=57 ; 55 \%)$ przyznaje, że skorzystanie z procedury prawnej w sytuacji, kiedy rodzice nie wyrażają zgody na leczenie z powodu swoich przekonań, jest „raczej” dobrym rozwiązaniem, 22\% $(n=23)$ ankietowanych uważa, że powinno się poszukać innego wyjścia, $16 \%(n=16)$ respondentów zdecydowanie przyznaje, że procedura prawna jest najlepszym sposobem w takiej sytuacji, zaś 7\% $(n=7)$ badanych ma zdecydowanie przeciwne zdanie. W doświadczeniu badanych, procedura prawna wdrażana jest zawsze wtedy, kiedy występuje zagrożenie życia dziecka na skutek decyzji rodziców dotyczącej odmowy leczenia krwią ( $n=33 ; 31,73 \%)$, zaś $25,96 \%$ $(\mathrm{n}=27)$ pielęgniarek nigdy nie spotkało się $\mathrm{z}$ taką sytuacją (tab. 4).
Tab. 4. Odpowiedzi badanych na temat wdrażania procedury prawnej w sytuacji odmowy rodziców dziecka na jego leczenie

\begin{tabular}{|l|c|c|}
\hline \multicolumn{1}{|c|}{ Odpowiedzi } & n & $\%$ \\
\hline Zawsze, kiedy występuje zagrożenie życia dziecka & 33 & 31,73 \\
\hline Nigdy nie spotkałam się z taką sytuacją & 27 & 25,96 \\
\hline $\begin{array}{l}\text { Bardzo rzadko, procedura prawna jest ważna tylko } \\
\text { w konkretnych ciężkich przypadkach }\end{array}$ & 23 & 22,12 \\
\hline $\begin{array}{l}\text { Zazwyczaj, kiedy proponowane leczenie (nie akceptowane } \\
\text { przez rodziców) jest najkorzystniejsze dla dziecka }\end{array}$ & 15 & 14,42 \\
\hline $\begin{array}{l}\text { Rzadko, gdyż są dostępne inne metody leczenia dziecka } \\
\text { (akceptowane przez rodziców) }\end{array}$ & 6 & 5,77 \\
\hline Suma & 104 & 100 \\
\hline
\end{tabular}

Pielęgniarki zapytano czy w ich miejscu pracy powyższa procedura prawna jest wdrażana niezwłocznie po przedstawieniu decyzji przez rodziców dziecka. Spośród wszystkich odpowiedzi, najczęściej padającą była "nie, po pierwsze prowadzone sa rozmowy w celu przekonania rodziców o zmianie decyzji” ( $\mathrm{n}=28 ; 26,92 \%)$, zaś najrzadziej „tak, ale procedura prawna wymaga upływu czasu" ( $n=12 ; 11,54 \%)$. Od udzielenia opinii powstrzymało się $2,88 \%(n=3)$ respondentów, podając odpowiedź "nie wiem” (tab. 5).

Tab. 5. Experiences of the respondents on the implementation of the legal procedure after presenting parents' decisions

\begin{tabular}{|l|c|c|}
\hline \multicolumn{1}{|c|}{ Odpowiedzi } & n & $\%$ \\
\hline $\begin{array}{l}\text { Nie, po pierwsze prowadzone są rozmowy w celu } \\
\text { przekonania rodziców 0 zmianie decyzji }\end{array}$ & 28 & 26,92 \\
\hline Zależy od stanu dziecka, którego leczenie krwią dotyczy & 26 & 25,00 \\
\hline $\begin{array}{l}\text { Nie, pierwsze informujemy rodziców o zamierzeniu } \\
\text { wdrożenia procedury prawnej a następnie dajemy czas } \\
\text { do powtórnego przemyślenia i ponownego określenia } \\
\text { swojego stanowiska }\end{array}$ & 19 & 18,27 \\
\hline $\begin{array}{l}\text { Tak, problem natychmiast zgłaszany jest do odpowiednich } \\
\text { instytucji }\end{array}$ & 16 & 15,38 \\
\hline Tak, ale procedura prawna wymaga upływu czasu & 12 & 11,55 \\
\hline Nie wiem & 3 & 2,88 \\
\hline Suma & 104 & 100 \\
\hline
\end{tabular}

Ponad połowa ankietowanych $(n=68 ; 65,38 \%)$ przyznała, że w swojej pracy zawodowej nie spotkała się z sytuacją by rodzice zmienili zdanie na temat leczenia krwią swojego dziecka, przed wdrożeniem procedury prawnej, zaś 34,62\% $(n=36)$ badanych odpowiedziało, że zdarzało się by rodzice zgodzili się na zaproponowane leczenie przez lekarza przed wdrożeniem procedury prawnej. Na pytanie „Czy Pani/Pana zdaniem istnieje inne, lepsze rozwiąanie poza obowiązujaca procedura prawna??", $83 \%$ badanych $(\mathrm{n}=86)$ przyznała, że nie ma innego lepszego rozwiązania niż obecna procedura prawna. Odmiennego zdania było $17 \%$ respondentek $(n=18)$, które uważają, że są inne lepsze rozwiązania np. rozmowa $z$ rodzicami bądź opiekunami prawnymi i przekonanie ich do zmiany decyzji.

Według zebranych danych, 14\% $(n=15)$ respondentów korzystało $\mathrm{z}$ porady prawnika w sytuacji trudnej moralnie oraz prawnie występującej w ich pracy, zaś pozostałe $86 \%(n=89)$ nie praktykowało takiego działania. Ponadto, 
$58,66 \%(n=61)$ badanych popiera funkcjonowanie tzw. eksperta ds. etyki zawodowej, który mógłby świadczyć pomoc w sytuacjach etycznie trudnych, 16,34\% $(n=17)$ jest przeciwnego zdania, a pozostali $25 \%(n=26)$ nie mają zdania na ten temat.

\section{WYNIKI BADAŃ}

Stanowisko Świadków Jehowy wobec transfuzji krwi wciąż stanowi wyzwanie medycyny i przedmiot dyskusji, przede wszystkim w ciężkich przypadkach klinicznych. Rozwój alternatywnych terapii oraz obowiązujące przepisy prawne zarówno w Polsce, jak i na świecie nie prowadzą do jednoznacznych rozwiązań i nie likwiduja konfliktów wartości, których w takich przypadkach doświadczaja i lekarze, i pielęgniarki $[2,7]$. Jest to szczególnie dotkliwe w sytuacji odmowy leczenia krwią dziecka [6]. Pomimo istnienia alternatywnych metod leczenia np. chirurgii bezkrwawej, to w codziennej praktyce klinicznej nie zawsze są one dostępne i kiedy leczenie krwią nie zostanie wdrożone, zagrożenie życia pacjenta staje się realne [8-10]. Jednocześnie, fakt odmowy leczenia krwią, nie oznacza, że Świadkowie Jehowy nie cenią życia i nie walczą o jego zachowanie szukając często agresywnych metod terapii. Oczekują jednak, aby te pozostawały zgodne $\mathrm{z}$ ich religijnymi przekonaniami $[3,10]$.

$\mathrm{Z}$ medycznego punktu widzenia stanowisko Świadków Jehowy w kwestii odmowy leczenia krwią wydaje się być irracjonalne [6]. Znajduje to swój wyraz w opinii badanych pielęgniarek pediatrycznych, z których $50 \%$ nie akceptuje stanowiska Świadków Jehowy w tej kwestii, a blisko $30 \%$ nie ma jednoznacznego zdania na ten temat.

Z badań własnych wynika, że najtrudniejszym doświadczeniem pielęgniarek w sytuacji odmowy leczenia krwią dziecka Świadków Jehowy jest narażenie dziecka na uratę zdrowia bądź nawet śmierć. Dla ochrony życia i zdrowia dziecka, wprowadzono procedurę prawną, która w sytuacji radykalnego sprzeciwu rodziców na leczenie dziecka krwią pozwala personelowi krew podać. Większość badanych pielęgniarek $(85,57 \%)$ uważa, że tego typu rozwiązania prawne są potrzebne i są dobrym rozwiązaniem (71\%). Podkreśla się, że zanim ta procedura zostanie wdrożona, powinny zostać wykorzystane wszystkie dostępne i akceptowane przez rodziców metody terapii, z założeniem ochrony bezpieczeństwa pacjenta. Dodatkowo, rodzice dziecka powinni być systematycznie i na bieżąco informowani o procesie postępowania i efektach podejmowanych działań $[3,5]$. W badaniach własnych pielęgniarki wskazały, że przed wdrożeniem procedury prawnej, prowadzone są rozmowy w celu przekonania rodziców o zmianie decyzji $(26,92 \%)$ oraz dawany jest im czas do przemyślenia i ponownego określenia swojego stanowiska (18,27\%). Jednocześnie, większość badanych $(65,38 \%)$ przyznała, że nie spotkała się z sytuacją by rodzice zmienili zdanie na temat leczenia krwią dziecka.

Z etycznego punktu widzenia, podkreśla się, że szczera komunikacja, bez elementów przymusu i taktyki straszenia, jest kluczem w takich sytuacjach. Komunikacja, a także empatia i wsparcie mogą pomóc rodzicom podjąć świadomą i dobrą decyzję $[3,5]$.

\section{WNIOSKI}

Najtrudniejszym doświadczeniem pielęgniarek w sytuacji odmowy leczenia krwią dziecka Świadków Jehowy jest w opinii badanych narażenie dziecka na uratę zdrowia czy nawet śmierć. Dlatego większość badanych uważa, że dobrym rozwiązaniem w takich przypadkach jest wdrożenie procedury prawnej, która pozwala na transfuzję pomimo sprzeciwu rodziców.

\section{PIŚMIENNICTWO/REFERENCES}

1. Dunn HP. Etyka dla lekarzy, pielęgniarek i pacjentów. Tarnów: Wyd. Biblos; 1997.

2. Pietrzkiewicz A. Przetaczanie krwi u Świadków Jehowy. Pielęgniarstwo Polskie 2011; 1 (39): 55-56.

3. Effa-Heap G. Blood transfusion: implications of treating a Jehovah's Witness patient Br J Nurs. 2009; 18(3): 174-177.

4. Spencer JR. A point of contention: The scriptural basis for the Jehovah's Witnesses' refusal of blood transfusions. Christian Bioethics. 2002; 8 (1): 63-90.

5. Wilson P. Jehowah's Witness children: when religion and the law collide. Pediatric Nursing. 2005; 17(3): 34-37.

6. Sagy I, Jotkowitz A, Barski L. Reflection on cultural preferences and internal medicine: the case of Jehovah's Witnesses and the changing thresholds for blood transfusions. J Relig Health. 2017; 56: 732-738

7. McInroy A. Blood transfusion and Jehovah's Witness Witnesses: the legal and ethical issues. Br J Nurs. 2005; 14 (5): 270-274.

8. Shaner DM, Prema J. Conversation and the Jehovah's Witness dying from blood loss. Narrat Inq Bioeth. 2014; 4 (3): 253-261.

9. Allen J, Berrios L, Solimine M, Knott-Craig CJ. Bloodless surgery in a pediatric Jehovah's Witness. Journal of Extra-Corporeal Technology. 2013; 45 (4): 251-253.

10. Ringnes H, Hegstad H. Refusal of Medical Blood Transfusions Among Jehovah's Witnesses: Emotion Regulation of the Dissonance of Saving and Sacrificing Life. J Relig Health. 2016; 55: 1672-1687.

Praca zgłoszona do czasopisma/Manuscript received: 24.08.2018

Praca zaakceptowana do druku/Manuscript accepted: 04.10 .2018

Tłumaczenie/Translation: Beata Chrust 